\title{
Impact of nuclear YAP1 expression in residual cancer after neoadjuvant chemohormonal therapy with docetaxel for high-risk localized prostate cancer
}

Yoshinori Matsuda ${ }^{1}$, Shintaro Narita ${ }^{1 *}$, Taketoshi Nara ${ }^{1}$, Huang Mingguo ${ }^{1}$, Hiromi Sato ${ }^{1}$, Atsushi Koizumi ${ }^{1}$, Sohei Kanda', Kazuyuki Numakura', Mitsuru Saito', Takamitsu Inoue ${ }^{1}$, Yuko Hiroshima², Hiroshi Nanjo², Shigeru Satoh ${ }^{3}$, Norihiko Tsuchiya ${ }^{4}$ and Tomonori Habuchi ${ }^{1}$

\begin{abstract}
Background: Although docetaxel-based chemohormonal therapy $(\mathrm{CHT})$ is one of the standard treatments for castration-resistant prostate cancer (CRPC), pertinent biomarkers and precise mechanisms involved in the resistance for CHT for CRPC remain unknown. We investigated the relationship between chemohormonal resistance and the expression of steroid receptors and Hippo pathway proteins using a docetaxel-resistant prostate cancer (PCa) cell line and human PCa tissues in patients who underwent surgery with and without neoadjuvant therapy.

Methods: A docetaxel-resistant subline (22Rv1-DR) was generated to assess Hippo pathway protein expression and the effect of YAP1 inhibition on cellular characteristics. A tissue microarray with 203 cores from 70 high-risk localized PCa tissues was performed to assess steroid receptor and Hippo pathway protein expressions.

Results: Nuclear YAP (nYAP) expression was higher in 22RV-1-DR than in parental 22Rv-1 and YAP1 knockdown suppressed cell proliferation of 22Rv1-DR. Steroid receptor and Hippo pathway protein expressions varied among three different neoadjuvant groups, and nYAP1 expression was the highest in the CHT group. The patients with high nYAP in residual cancer after neoadjuvant $\mathrm{CHT}$ had a significantly higher biochemical recurrence (BCR) rate than those with low nYAP1. On multivariate analysis, the high nYAP1 was an independent prognostic factor for BCR.
\end{abstract}

Conclusions: nYAP expression is a potential biomarker in high-risk patients treated with docetaxel-based CHT. Steroid receptors and Hippo pathway proteins may play a role in the chemohormonal resistance in advanced PCa.

Keywords: YAP1, Residual cancer, Neoadjuvant chemohormonal therapy, Docetaxel, Prostate cancer, High-risk

\section{Background}

Prostate cancer (PCa) is one of the most common cancers and the major leading cause of cancer-related death in men worldwide [1]. A recent epidemiological study showed that PCa had the highest incidence of cancer for

\footnotetext{
* Correspondence: nari6202@gipc.akita-u.ac.jp

'Department of Urology, Akita University School of Medicine, 1-1-1 Hondo, Akita 010-8543, Japan

Full list of author information is available at the end of the article
}

men in 92 countries and the leading cause of cancer deaths for men in 48 countries [2]. Although androgen deprivation therapy (ADT) is a mainstay treatment for advanced $\mathrm{PCa}$, eventually all patients develop conventional ADT-resistant cancer, known as castrationresistant prostate cancer (CRPC). After two large phase III randomized trials demonstrated that docetaxel-based chemotherapy improved the survival of patients with CRPC [3, 4], docetaxel-based chemotherapy is one of

(c) The Author(s). 2020 Open Access This article is licensed under a Creative Commons Attribution 4.0 International License, which permits use, sharing, adaptation, distribution and reproduction in any medium or format, as long as you give appropriate credit to the original author(s) and the source, provide a link to the Creative Commons licence, and indicate if changes were made. The images or other third party material in this article are included in the article's Creative Commons licence, unless indicated otherwise in a credit line to the material. If material is not included in the article's Creative Commons licence and your intended use is not permitted by statutory regulation or exceeds the permitted use, you will need to obtain permission directly from the copyright holder. To view a copy of this licence, visit http://creativecommons.org/licenses/by/4.0/ The Creative Commons Public Domain Dedication waiver (http://creativecommons.org/publicdomain/zero/1.0/) applies to the data made available in this article, unless otherwise stated in a credit line to the data. 
the standard treatments for CRPC. However, a significant heterogeneity was found in the response of patients to ADT and/or chemotherapy, and most patients become refractory due to the development of drug resistance. Therefore, the identification of key regulators of resistance to both hormonal therapy and chemotherapy in patients with advanced $\mathrm{PCa}$ is warranted.

Recent randomized phase III trials have shown that the combination therapy of ADT plus docetaxel for newly diagnosed metastatic hormone-naive PCa provides significant survival benefits compared with ADT alone $[5,6]$. However, whether the same extent of benefit is obtained if these therapies are applied at an earlier stage, such as high-risk localized $\mathrm{PCa}$, remains controversial. We previously reported the outcomes of neoadjuvant chemohormonal therapy (CHT) combined with ADT, docetaxel, and estramustine phosphate, followed by radical prostatectomy (RP) $[7,8]$. In these studies, we found the limitation of the effect of CHT in patients with high-risk localized $\mathrm{PCa}$, therefore indicating the importance of elucidating the molecular mechanisms underlying the resistance to docetaxel-CHT to overcome resistance and improve the outcome for the treatment of high-risk localized PCa.

Numerous previous studies have hypothesized that mechanisms and pathways are implicated in the development of resistance to ADT and docetaxel in PCa [9-11]. Both androgen receptor (AR)-dependent and -independent mechanisms were considered to be associated with resistance for PCa treatment [12]. Based on tissue biomarker analyses, the expression of AR signaling, steroid synthesis pathway, intracellular signaling, stromal-epithelial interaction, hedgehog signaling, and angiogenesis pathway were considered to be biomarkers for drug resistance and prognoses in patients treated with neoadjuvant chemotherapy and CHT, followed by RP $[13,14]$.

The Hippo pathway is known to regulate tissue homeostasis, organ size, and tumorigenesis, and exerts a significant impact on cancer development by modulating cell proliferation, apoptosis, and stemness in response to a wide range of extra- and intracellular signals, including cell-cell contact, cell polarity, mechanical cues, ligands of G-protein-coupled receptors, and cellular energy status [15]. Moreover, increased nuclear localization and higher transcriptional activities of YAP/TAZ, main transcriptional regulators in the Hippo pathway, have been observed in therapy-resistant malignancies [16]. With regard to the relationship between Hippo signaling and $\mathrm{PCa}$, a recent study showed that YAP1 and AR are colocalized and interact with each other predominantly within the cell nuclei by an androgen-dependent mechanism in hormone-naive $\mathrm{PCa}$ and an androgenindependent mechanism in CRPC cells [17]. Moreover, recent studies have shown that the Hippo pathway is involved in docetaxel-resistance of prostate cancer [18, 19]. However, the impact of Hippo pathway proteins on $\mathrm{ADT}$ - and chemotherapy-resistant $\mathrm{PCa}$ progression remains unknown. In particular, no study has evaluated the expression levels of the Hippo pathway proteins in PCa patients with and without neoadjuvant treatment.

In this study, we investigated Hippo pathway protein expression and the effect of YAP1 inhibition on cellular characteristics such as proliferation, apoptosis and the cell cycle in a docetaxel-resistant PCa cell line. Moreover, the tissue expression of candidate biomarkers, including Hippo pathway proteins and steroid receptors, was assessed using human $\mathrm{PCa}$ tissues in patients who underwent RP with and without neoadjuvant therapy to identify tissue biomarkers in patients with high-risk PCa treated with $\mathrm{CHT}$ and to explore novel targets for chemohormonal resistance for advanced $\mathrm{PCa}$.

\section{Methods \\ Cell lines}

Human PCa 22Rv1 cells were obtained from the American Type Cell Culture Collection (Manassas, VA, USA). The cells were authenticated with short-tandem repeat analysis (Bio-Synthesis, Lewisville, TX, USA). The docetaxel-resistant subline of 22Rv1 cell (22Rv1-DR), which has a characteristic of androgen- and ligandindependent growth $[20,21]$, was established in the presence of increasing concentrations of docetaxel (Sigma-Aldrich, St. Louis, MO, USA) up to the final concentration of $5 \mathrm{nM}$, which is the $\mathrm{IC}_{50}$ concentration in our pilot study. Development of the drug-resistant cell line took $\geq 4$ months and further studies using sublines cultured for $\geq 4$ months that were based on the results of MDR1 expression in the cells were performed. The cells were cultured in RPMI 1640 medium (Invitrogen, Carlsbad, CA, USA) containing 10\% fetal bovine serum (FBS) in a $5 \% \mathrm{CO}_{2}$ humidified incubator at $37^{\circ} \mathrm{C}$ and passaged for 3-4 days in a fresh medium to achieve approximately 80\% confluency. SiYAP1 (SI02662954) and negative control siRNA (AllStars Negative Control siRNA) were purchased from Qiagen (Valencia, CA). Transfections of siRNAs were performed by using Lipofectamine 3000 (Invitrogen) according to the manufacturer's procedure.

\section{Cell proliferation assay}

A non-radioactive MTT-based cell proliferation assay kit (Roche, Switzerland) was used based on the manufacturer's instructions. The proliferation assays were performed in triplicate. A total of $1.0 \times 10^{4} 22 \mathrm{Rv} 1$ cells were seeded into each well of a 24-well plate and incubated for $72 \mathrm{~h}$ with fresh media containing 10\% FBS. Absorbance was measured using an enzyme-linked immunosorbent assay reader (BIO RAD, Hercules, CA, USA). 


\section{Apoptosis and cell cycle analyses}

Equal numbers of $22 \mathrm{Rv} 1-\mathrm{DR}$ cells $\left(5 \times 10^{5}\right)$ were plated into a six-well plate. Three day later, the cells were treated with $25 \mathrm{nM}$ siRNAs. For apoptosis and cell cycle analyses, the cells were analyzed by using a Cycletest Plus DNA Reagent kit (BD Biosciences, Franklin Lakes, NJ, USA) according to the manufacturer's protocol. The rate of apoptosis and fraction of each cell cycle phase (subG0,G0-G1, S, G2) were examined by using a FACSCalibur flow cytometry system (BD Biosciences, Franklin Lakes, NJ, USA).

\section{Western blot analysis}

Total proteins were isolated using complete Lysis-M buffer (Roche). The protein concentration was measured using the ND-1000 method (Thermo Fisher Scientific). Equal amounts of protein lysates were separated by sodium dodecyl sulfate polyacrylamide gel electrophoresis and transferred using the iBot ${ }^{\bullet}$ Blotting System (Invitrogen). The membranes were blocked for $1 \mathrm{~h}$ at room temperature with a buffer containing $2 \%$ bovine serum albumin in Tris-buffered saline with $0.1 \%$ Tween-20. The membranes were incubated overnight in the diluted antibodies and blocked with secondary immunoglobulin G (IgG) antibody for $1 \mathrm{~h}$. Specific proteins were detected using the ECL prime western blotting detection reagent (Amersham Biosciences, Buckinghamshire, UK). The monoclonal/polyclonal antibodies, including PARP, MDR1, YAP1 (= YAP, YAP65), p-YAP, TAZ, $\beta$-actin, Lamin A/C (Cell Signaling Technology), MOB1B (= MOB4A, Abgent), and TEAD1 (BD Biosciences, city, US state, country), were used. Nuclear and cytoplasmic fractions were prepared using the NE-PER Nuclear and Cytoplasmic Extraction reagents based on the manufacturer's instruction (Thermo Fisher Scientific).

\section{Patients}

The patients were prospectively enrolled in the phase II study to assess the impact of CHT with ADT, docetaxel, and estramustine phosphate, followed by RP in patients with high-risk PCa between 2006 and 2016 at our institution [7, 8]. Eligible patients had histopathologically confirmed localized, high-risk PCa and were candidates for RP at our hospital as reported previously $[7,8]$. The patients were excluded if they had received prior therapy for $\mathrm{PCa}$, prior invasive malignancy, any serious comorbidity, or an Eastern Cooperative Oncology Group performance status of $\geq 2$. All the patients provided written informed consent, and the study was approved by the institutional review board of Akita University (Ethical Approval No. 1341). A "high-risk" disease was defined as any of the following conditions: $\geq \mathrm{cT} 3$, preoperative PSA level of $\geq 15 \mathrm{ng} / \mathrm{mL}$, and/or a Gleason pattern of 5 in primary and/or secondary. Supplementary Table 1 describes the patient characteristics in the $\mathrm{CHT}$ group. To establish the tissue microarray (TMA), we also included patients with $\mathrm{PCa}$ with our high-risk criteria who underwent RP without any neoadjuvant therapy (no neoadjuvant: NNA) and with neoadjuvant hormonal therapy (NHT) for $>3$ months in the same period.

\section{Treatment regimen}

Supplementary Figure 1 shows the schedule of $\mathrm{CHT}$ at our institution [8]. Briefly, the CHT protocol involved combined androgen blockade with $11.25 \mathrm{mg}$ leuprorelin or goserelin subcutaneously once every 3 months and 81 mg bicalutamide orally for the first 12 weeks. Docetaxel at a dose of $30 \mathrm{mg} / \mathrm{m}^{2}$ was administered intravenously, with $560 \mathrm{mg}$ of estramustine phosphate orally for 6 consecutive weeks. The clinical outcomes of the study have been reported in previous literature $[7,8]$.

\section{Tissue microarrays and immunohistochemical analyses}

A TMA was constructed at the Pathology Institute, Toyama, Japan, using paraffin blocks of primary prostatectomy tissues from the patients treated at our institute. Briefly, two independent pathologists (H.N. and Y.H.) blinded to the identity of the patient associated with each tissue analyzed the hematoxylin and eosin-stained sections of each paraffin block, and the area of residual $\mathrm{PCa}$ within each section was identified. Triplicated cores measuring $0.6 \mathrm{~mm}$ in diameter were collected randomly from the cancerous areas and transplanted to the TMA. Tissues were excluded if no residual cancerous regions in the prostate (pT0) were found. As a result, a TMA had 210 cores from 70 high-risk patients with localized PCa who underwent RP with NNA $(n=15)$, with NHT $(n=11)$, or with CHT $(n=44)$ (Supplementary Fig. 2). In establishing the TMA, seven cores were excluded as part of the TMA slide. Therefore, the final number of cores embedded in the TMA was 203. The expression of six candidate biomarkers, including steroid receptors (AR, glucocorticoid receptor [GR], progesterone receptor $[\mathrm{PR}]$, and estrogen receptor alpha $[\mathrm{ER} \alpha])$, and Hippo pathway proteins (YAP1 and MOB4A), were statistically assessed using immunohistochemistry (IHC). Supplementary Table 2 lists the antibodies used in this study. The IgG isotype controls were used as a negative control. To assess the expression of tissue markers, the intensity of IHC staining was scored and stratified into four groups: negative (0), weak (1), moderate (2), and strong (3). The area of IHC staining was also stratified into five groups: $0 \%(0),<25 \%(1),<50 \%(2),<75 \%(3)$, and $100 \%$ (4). Subsequently, the intensity, area, and immunoreactivity scores, which were determined by multiplying the intensity and area [22], were evaluated. Cytoplasmic AR and GR expressions were indicated as negative or positive. The cores were excluded from 
scoring if determining the scores was difficult due to peeling off of a part of the tissue from the slide and if there were no adequate residual cancer epithelial cells in the section. The differential expression of the six biomarkers between the three groups and the impact of expression scores on biochemical recurrence $(\mathrm{BCR})$ in the CHT group were statistically assessed.

\section{Statistical analyses}

Immunohistochemical scores were reported as means \pm standard errors. Differences in the scores of immunohistochemical staining among the three groups were evaluated using the chi-squared test and analysis of variance. Differences of expression levels of biomarkers in the NNA and NHT groups were statistically compared with those in the CHT group using the chi-squared test and the Mann-Whitney $U$ test for categorical and continuous variables, respectively. The date of BCR was defined as that when the serum PSA level exceeded $0.2 \mathrm{ng} / \mathrm{mL}$ or when adjuvant or salvage therapy was initiated even if PSA did not exceed $0.2 \mathrm{ng} / \mathrm{mL}$. BCR-free survival was calculated using the Kaplan-Meier method with logrank tests for between-group comparisons. Independent prognostic factors were identified by univariate analysis (i.e., patient age, baseline PSA level, Gleason score at diagnosis, CHT completion, extended lymph node dissection, pathological $\mathrm{T}$ stage, pathological $\mathrm{N}$ stage, positive surgical margin, and scores of immunostaining of the six biomarkers). Significant preoperative variables in univariate analyses $(p<0.05)$ were included in multivariable analyses, which were performed using the Cox proportional hazards regression model. SPSS, version $24.0^{\circ}$ (SPSS Inc., Chicago, IL, USA) was used for statistical analysis, and all $p$-values were two-sided and considered significant when $<0.05$.

\section{Results}

Establishment of docetaxel-resistant 22Rv1 sublines and hippo pathway protein expression

First, we established the 22Rv1-DR cell subline, which was resistant to various concentrations of docetaxel, compared with the parental 22Rv1 cell (Fig. 1a). The $\mathrm{IC}_{50}$ at $72 \mathrm{~h}$ in the 22Rv1-DR cells was significantly higher than that in the parental 22Rv1 cells (7.92 vs $2.39 \mathrm{nmol} / \mathrm{L}$, respectively, $p=0.002$ ). To confirm the resistance to apoptosis after docetaxel treatment, the PARP expression in parental 22Rv1, 22Rv1-DR, and two cell lines after docetaxel treatment with different durations of exposure was determined (Fig. 1b, sFig.3). The cleaved PARP was observed in the parental 22Rv1 treated for $72 \mathrm{~h}$ with $5 \mathrm{nmol} / \mathrm{L}$ of docetaxel, whereas no cleaved PARP expression was shown in the 22Rv1-DR up to $72 \mathrm{~h}$ after treatment of docetaxel (Fig. 1b, sFig.3). The results confirmed that the 22Rv1-DR subline was resistant to apoptosis induced by docetaxel treatment. Consistent with the previous reports [23, 24], the expression of MDR-1, which is a robust drug pump, was markedly higher in the 22Rv1-DR sublines than that in the parental 22Rv1 (Fig. 1c, sFig.4). Using the cell lines, the expression and activation of Hippo pathway proteins, including YAP1, TAZ, MOB4A, and TEAD1, were subsequently compared in 22Rv1-DR and 22Rv1 cells (Fig. 1d, sFig.5). These four proteins are known to be key regulators of Hippo pathway signaling [15]. With regard to Hippo pathway protein expression in the whole lysates, no difference in expression was found in YAP, p-YAP, and MOB4A between the parental 22Rv1 and 22RV1DR cells (Fig. 1d). In the nuclear fraction of lysates, nuclear YAP1 (nYAP1) and p-YAP1 expressions in 22Rv1-DR were markedly higher than those in 22Rv1, whereas nuclear TEAD1 expression was lower in 22Rv1DR (Fig. 1d, sFig.5). Consistent with the previous study [25], TAZ was not expressed in 22Rv1 and its sublines (data not shown), suggesting that nYAP1 expression and activation were associated with chemotherapy resistance in the 22Rv1 PCa cell line and that nYAP1 expression and activation have a potential to be associated with chemohormonal resistance for PCa.

\section{Effect of YAP1 knockdown on cellular characteristics in the 22Rv1-DR cells}

Next, the effects of YAP1 knockdown on cell proliferation, apoptosis and the cell cycle in established 22Rv1DR cells were investigated. In the 22Rv1-DR cells, siYAP1 significantly suppressed the level of YAP1 mRNA in a time-dependent manner (Fig. 2a). Figure $2 b$ showed significant reduction of cell proliferation of 22Rv1-DR cells after treatment with YAP1 siRNA relative to that after treatment with control siRNA at 4 and 6 days after transfection of siRNAs $(p=0.038, p=0.049$, respectively,). Regarding induction of apoptosis, there was no significant difference in the fraction of 22Rv1-DR cells undergoing apoptosis (sub G1-G0 fraction) between the cells treated with siYAP1 and those treated with the control siRNA at 24 and $48 \mathrm{~h}$ after transfection $(p=$ $0.439, p=0.613$, Fig. $2 \mathrm{c}$ and d). Moreover, there were no significant differences in the percentages of 22Rv1-DR cells in the G0/G1, S and G2 fractions between the cells treated with siYAP1 and those treated with control siRNA at 24 and $48 \mathrm{~h}$ after transfection (Fig. 2c and d). These results suggested that YAP1 knockdown inhibits cell growth of the 22Rv1-DR cells without induction of apoptosis and modulation of cell cycle arrest.

Expression of tissue biomarkers in human prostate tissues among three different neoadjuvant treatment groups

Subsequently, the difference of expression of six candidate tissue biomarkers, including the Hippo pathway 


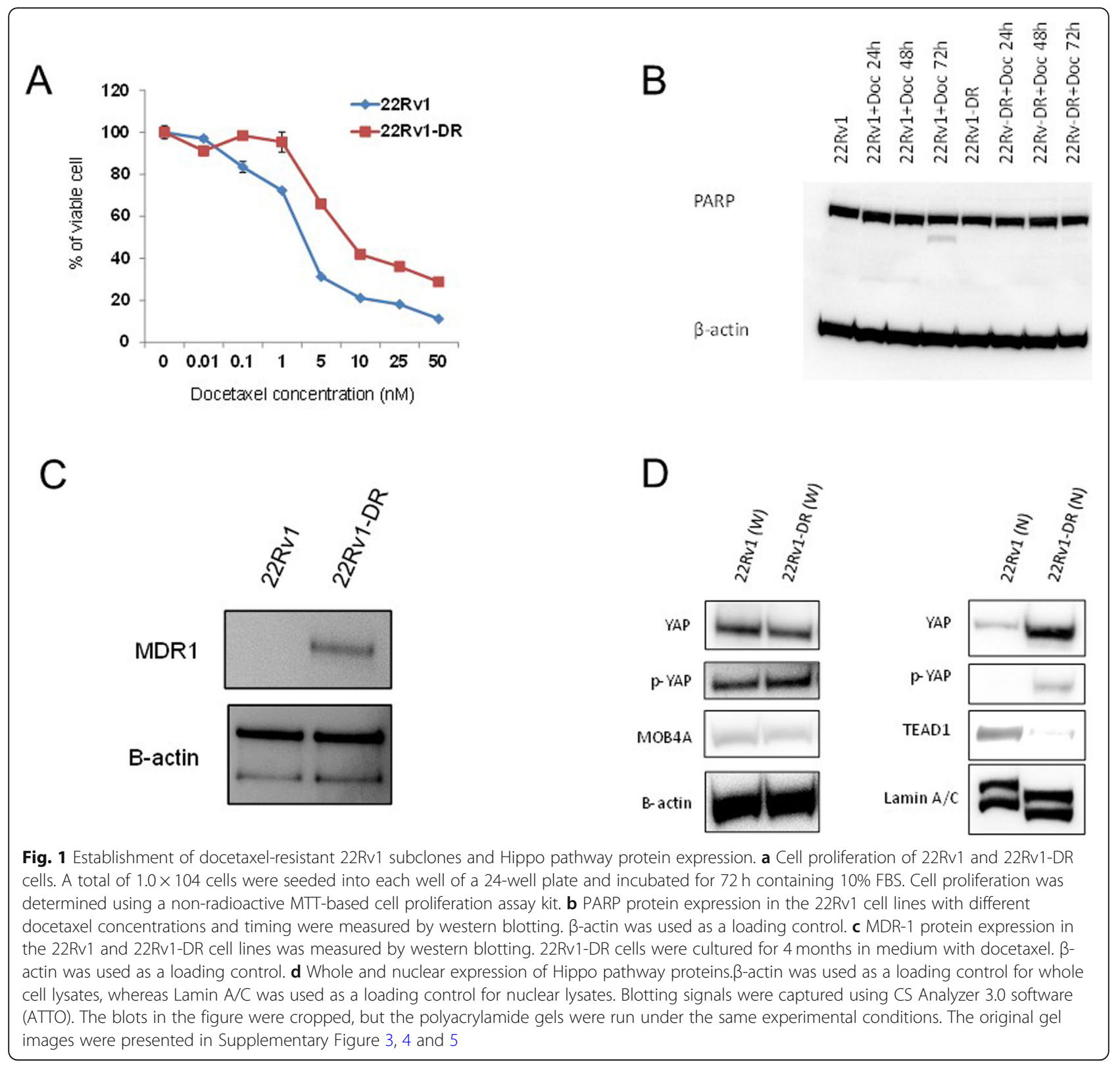

proteins (YAP1 and MOB4A) with steroid receptors (AR, GR, PR, and ER $\alpha$ ), which were known to play a key role in PCa progression and resistance [26-28], among the three groups with different neoadjuvant treatments by the IHC analyses was investigated. AR and GR expressions were observed in the nucleus and cytoplasm of residual cancer cells and stromal cells in prostate tissues (Fig. 3), whereas ER $\alpha$ and PR expressions were expressed mainly in the stromal cells of prostate tissues (Fig. 3). With regard to the Hippo pathway proteins, YAP1 was expressed in both the nucleus and the cytoplasm, whereas MOB4A was expressed mainly in the cytoplasm (Fig. 3). Using core-based scoring analyses, AR, GR, PR,
ER $\alpha$, YAP1, and MOB4A expressions among the three groups with various neoadjuvant settings were compared (Table 1). The mean nuclear AR (nAR) immunoreactivity score in residual cancer cells in the CHT group was significantly lower than that in the NNA group (4.16 \pm 0.18 vs. $7.20 \pm 0.39$, respectively, $p<0.001$ ), whereas no difference of the nAR immunoreactivity score was found between the NHT and CHT groups $(4.16 \pm 0.18$ vs. $4.50 \pm 0.40$, respectively, $p=0.441$, Fig. $4 \mathrm{a})$. The mean nuclear GR imunoreactivity score in the residual cancer cells in the CHT group was significantly higher than that in the NNA ( $4.83 \pm 0.20$ vs. $3.35 \pm 0.29$, respectively, $p<$ $0.001)$ and NHT groups $(4.83 \pm 0.20$ vs. $3.38 \pm 0.37$, 


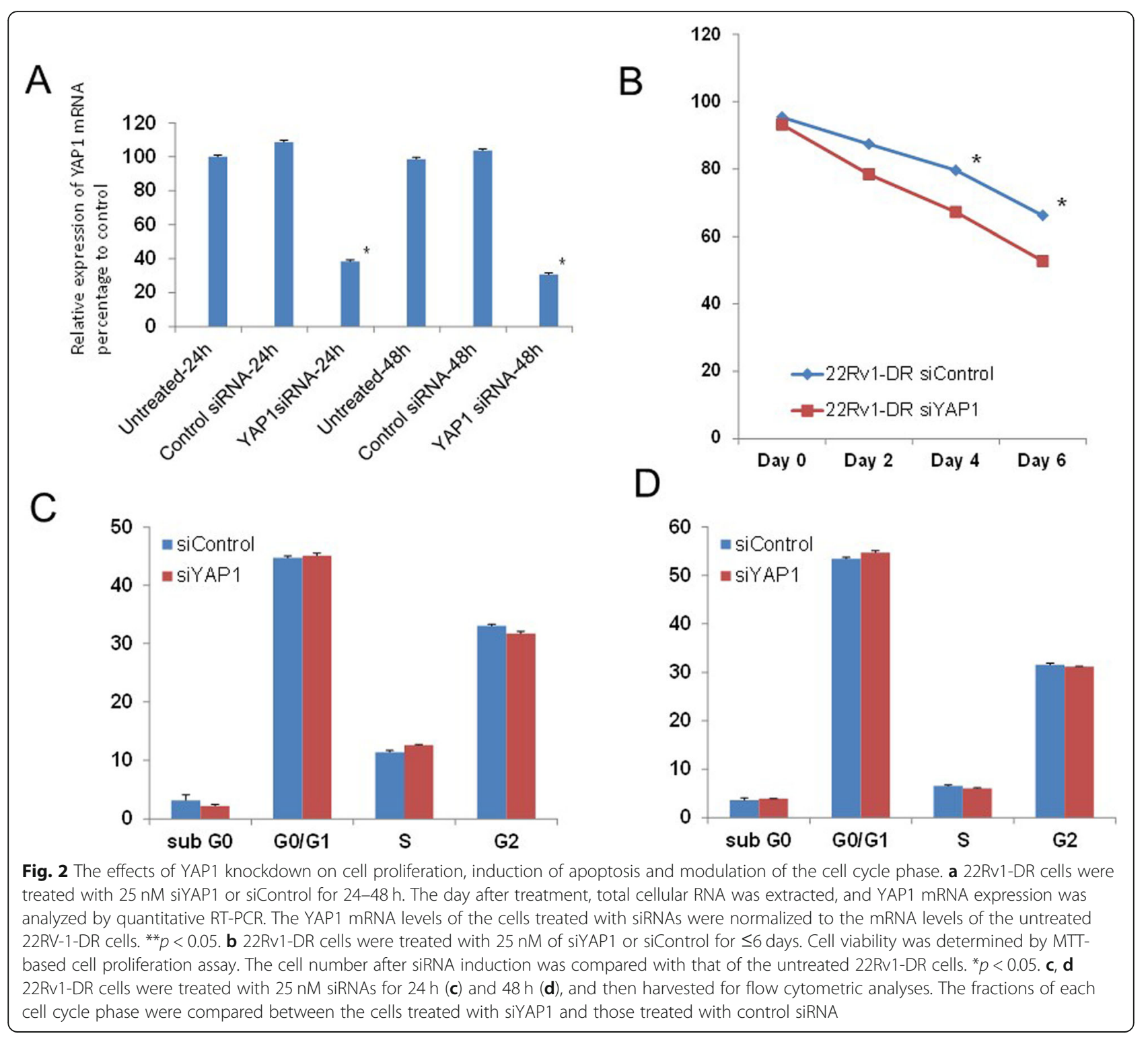

respectively, $p=0.001$, Fig. $4 \mathrm{~b})$. The mean nuclear PR immunoreactivity score in stromal cells in the CHT group was significantly higher than that in the NNA $(6.76 \pm 0.14$ vs. $2.85 \pm 0.19$, respectively, $p<0.001)$ and NHT groups ( $6.76 \pm 0.14$ vs. $3.75 \pm 0.24$, respectively, $p<$ 0.001 , Fig. 4c). With regard to Hippo pathway protein expression in the TMA, the mean nYAP area and intensity in the residual cancer cells in the CHT group were significantly higher than those in the NHT group ( $1.76 \pm 0.06$ vs. $1.27 \pm 0.15, p=0.002$; and $1.78 \pm 0.05$ vs. $1.27 \pm 0.15, p=0.002$, respectively). The mean cytoplasmic YAP1 immunoreactivity score in residual cancer cells in the CHT group was significantly higher than that in the NNA ( $4.71 \pm 0.20$ vs. $2.57 \pm 0.26$, respectively, $p<$ $0.001)$ and NHT groups $(4.71 \pm 0.20$ vs. $2.90 \pm 0.32$, respectively, $p<0.001)$. The nYAP1 immunoreactivity score of residual cancer cells in the CHT group was the highest, although no statistical differences were found among the three groups (Fig. 4d). The mean immunoreactivity score of cytoplasmic MOB4A in the CHT group was significantly higher than that in the NNA $(4.09 \pm 0.13 \mathrm{vs}$. $2.93 \pm 0.24$, respectively, $p<0.001)$ and NHT groups $(4.09 \pm 0.13$ vs. $3.20 \pm 0.31$, respectively, $p=0.004)$. Taken together, the expression changes of the six biomarkers in PCa tissues after the neoadjuvant treatments followed by $R P$ varied. However, several markers, including nuclear GR, stromal PR, nYAP1, and cytoplasmic MOB4A, were upregulated in the CHT group, whereas nAR was downregulated after neoadjuvant treatments with androgen deprivation and/or chemotherapy. 


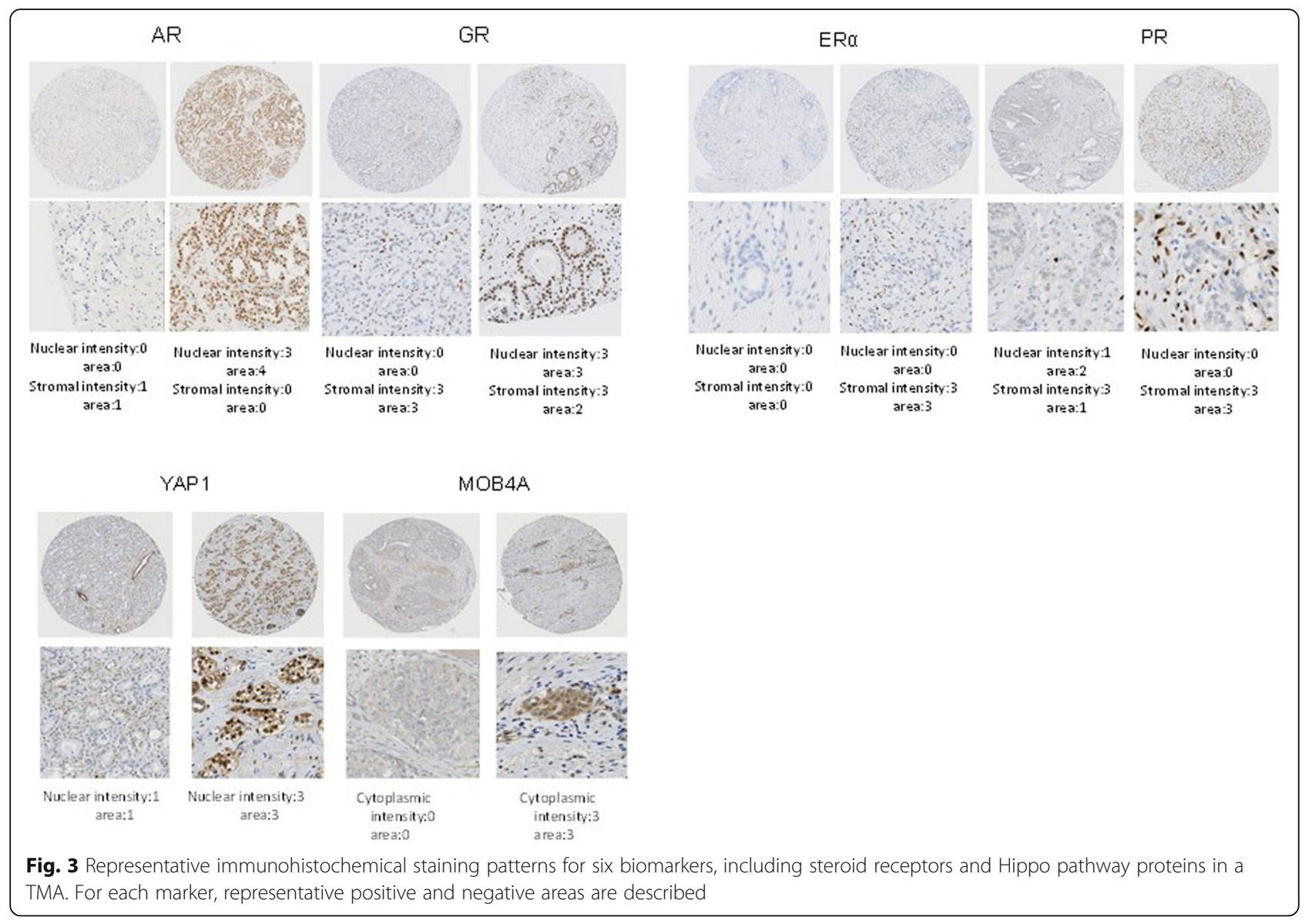

\section{Kaplan-Meier estimates of risk factors for $\mathrm{BCR}$ in high-risk PCa treated with $\mathrm{CHT}$, followed by RP}

To assess the impact of biomarkers for prognosis, univariate analysis of risk factors for BCR was conducted in patients with high-risk PCa treated with CHT, followed by RP. In the univariate analyses, age, baseline PSA level, pathological $\mathrm{T}$ stage $(\geq \mathrm{T} 3)$, pathological $\mathrm{N}$ (N1), nAR expression in residual cancer cells, and nYAP1 expression in residual cancer cells were significantly associated with $\mathrm{BCR}(p=0.035, p=$ $0.006, p<0.001, p=0.001, p=0.017, p=0.033$, respectively, Table 2, Fig. 5). Moreover, the patients with low nuclear PR expression in stromal cells tended to have a lower BCR-free survival than those with high PR expression $(p=0.054)$. On multivariable analysis, baseline PSA level, pN1, and high nYAP intensity in residual cancer cells were independent prognostic factors for $\mathrm{BCR}$ in patients with $\mathrm{PCa}$ treated with $\mathrm{CHT}$, followed by RP (hazard ratio $[\mathrm{HR}]=1.03 ; 95 \%$ confidence interval $[\mathrm{CI}], 1.01-1.05$, $p=0.010 ; \quad \mathrm{HR}=3.94 ; 95 \% \mathrm{CI}, 1.06-14.62, \quad p=0.040$; $\mathrm{HR}=3.32 ; 95 \% \mathrm{CI}, 1.32-8.37, p=0.011$; respectively, Table 2).

\section{Discussion}

In this study, we developed a docetaxel-resistant subline of PCa cells and showed that nYAP1 was overexpressed and highly activated in these cell lines and YAP1 knockdown in the docetaxel-resistant sublines suppressed cell proliferation in vitro. Furthermore, we established that TMA consisted of human PCa tissues extracted from surgery with various neoadjuvant settings. The expression of several steroid receptors and Hippo pathway-related proteins, including nYAP1, were up- and downregulated in the residual cancer and stromal cells in patients with $\mathrm{PCa}$ who underwent $\mathrm{CHT}$ compared with those treated with NNA and NHT. Notably, we found that nYAP1 expression in residual cancer cells is an independent prognostic marker for BCR in high-risk patients with $\mathrm{PCa}$ who underwent RP after CHT, suggesting that high levels of nYAP1 may potentially be a tissue biomarker for poor outcomes after surgery and play an important role in chemohormonal resistance in patients with PCa.

A key finding in the present study was that nYAP1 expression was strongly associated with poor BCR-free survival in patients with high-risk localized $\mathrm{PCa}$ treated 


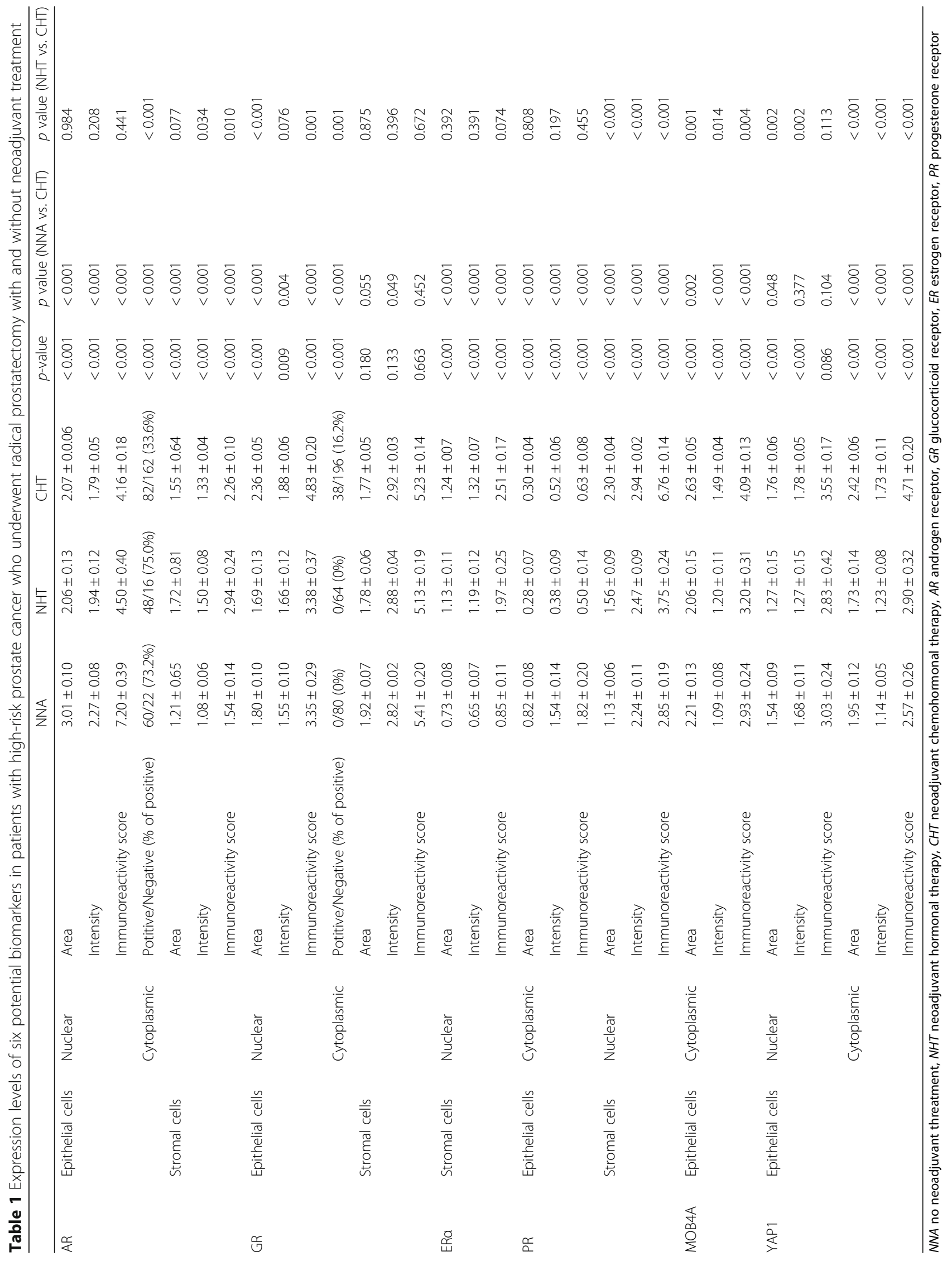



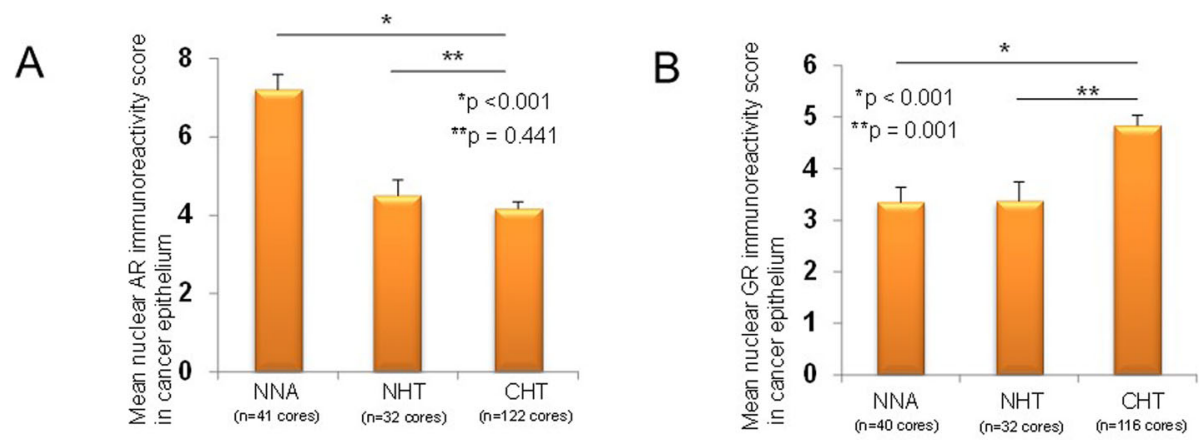

C
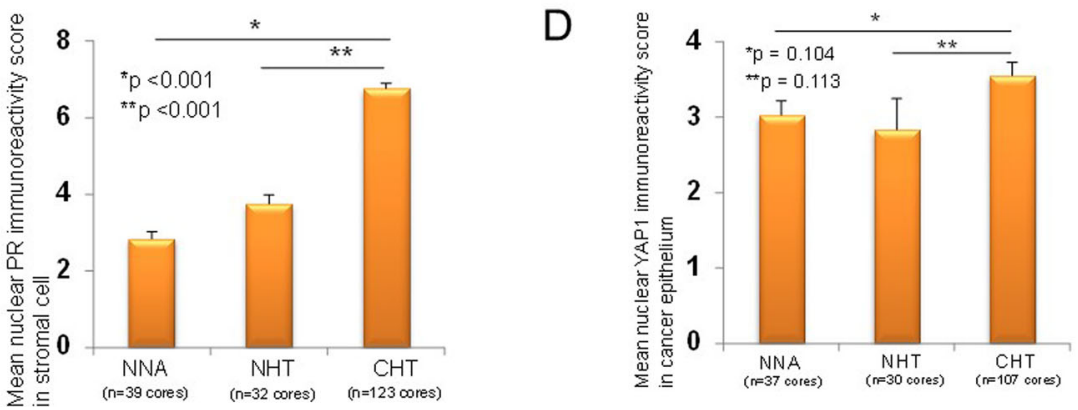

Fig. 4 The expression of tissue biomarkers among three different neoadjuvant treatment groups. The mean immunoreactivity score in cancer and stromal cells among the three groups, including NNA, NHT, and $\mathrm{CHT}$, are described. The statistical differences of the mean immunoreactivity score of NHT and CHT compared with NNA were statistically evaluated. ${ }^{*} p<0.05$. Nuclear expression of $\mathbf{a}$ AR in residual cancer cells, $\mathbf{b}$ GR in residual cancer cells, $\mathbf{c}$ PR in stromal cells, and $\mathbf{d}$ YAP1 in residual cancer cells

Table 2 Univariate and multivariable analysis for biochemical recurrence-free survival in patients with high-risk prostate cancer who underwent radical prostatectomy with and without neoadjuvant treatment

\begin{tabular}{|c|c|c|c|c|c|c|}
\hline \multirow[t]{2}{*}{ Variables } & \multicolumn{3}{|c|}{ Univariate } & \multicolumn{3}{|c|}{ Multivariable } \\
\hline & $\mathrm{HR}$ & $95 \% \mathrm{Cl}$ & $P$ value & $\mathrm{HR}$ & $95 \% \mathrm{Cl}$ & $P$ value \\
\hline Age & 0.92 & $0.85-1.00$ & 0.035 & & & \\
\hline Completion of NAC (medify vs complete) & 0.84 & $0.35-2.02$ & 0.689 & & & \\
\hline Baseline PSA level (continuous) & 1.02 & $1.01-1.04$ & 0.006 & 1.03 & $1.01-1.05$ & 0.010 \\
\hline Gleason score at diagnosis ( $\geq 8$ vs $\leq 7$ ) & 2.00 & $0.74-5.38$ & 0.169 & & & \\
\hline Extended lymph node dissection (yes vs no) & 1.51 & $0.60-3.81$ & 0.382 & & & \\
\hline $\mathrm{p} \top(\geq 3$ vs $\leq 2)$ & 4.40 & $1.91-10.13$ & $<0.001$ & 1.13 & $0.30-4.22$ & 0.854 \\
\hline $\mathrm{pN}(+$ or 0$)$ & 4.60 & $1.90-11.11$ & 0.001 & 3.94 & $1.06-14.62$ & 0.040 \\
\hline Resective margin (positive or negative) & 2.00 & $0.46-8.67$ & 0.355 & & & \\
\hline Nuclear expression of AR in epitherial cell (High vs low) & 3.00 & $1.22-7.35$ & 0.017 & 0.98 & $0.32-3.02$ & 0.971 \\
\hline Nuclear expression of GR in epitherial cell (High vs low) & 1.82 & $0.79-4.18$ & 0.161 & & & \\
\hline Nuclear expression of ERa in stromal cell (High vs low) & 2.37 & $0.84-6.64$ & 0.101 & & & \\
\hline Nuclear expression of PR in stromal cell (High vs low) & 0.45 & $0.20-1.02$ & 0.054 & & & \\
\hline Nuclear expression of YAP in epitherial cell (High vs low) & 2.44 & $1.08-5.55$ & 0.033 & 3.32 & $1.32-8.37$ & 0.011 \\
\hline Cytoplasmic expression of MOB4A in epitherial cell (High vs low) & 1.73 & $0.77-3.91$ & 0.190 & & & \\
\hline
\end{tabular}




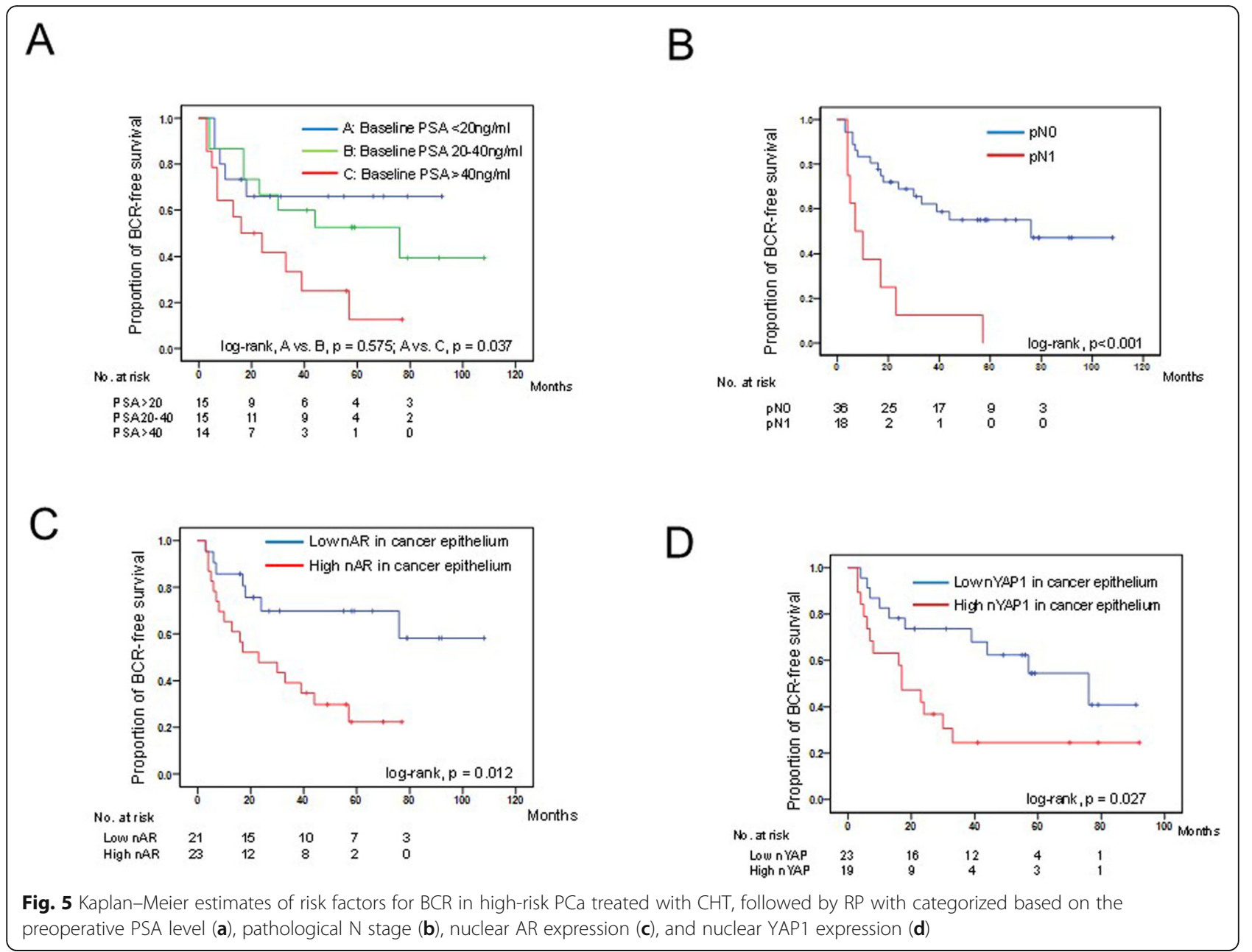

with CHT. YAP1 was known to be associated with therapy resistance of cancer treatment [16]. A number of studies demonstrated that increased nuclear localization of YAP-TAZ and higher transcriptional activities of YAP/TAZ target genes have been observed in therapyresistant tumors $[16,29,30]$. With regard to the relationship between YAP1 and PCa, Jiang et al. conducted a mass spectrometry-based quantitative proteomic approach and used it to compare protein phosphorylation in orthotopic xenograft tumors grown in either intact or castrated mice [31]. Their study showed that increased YAP1 levels in castration-resistant tumors and pharmacologic inhibitors of PAK2 (PF-3758309) and YAP1 (Verteporfin) inhibited the growth of androgenindependent PC3 xenografts. In a study by Zhang et al., the YAP1 mRNA was associated with androgeninsensitive $\mathrm{PCa}$ cells (LNCaP-C81 and LNCaP-C4-2 cells) compared with the level in androgen-sensitive LNCaP cells, and YAP1 confers castration resistance in vivo [32], strongly suggesting that YAP1 expression was associated with aggressive-phenotype $\mathrm{PCa}$, particularly in the treatment-resistant stage. In the present study, we showed that YAP1 knockdown in the 22Rv1DR cells attenuated cell proliferation without induction of apoptosis and cell cycle modulation, which indicated that future studies are needed to assess the other cellular responses in order to clarify the underlying mechanisms of YAP1-induced drug-resistance in PCa cells. Evidence on YAP1 expression in human tissues is limited; however, the rate of strong nucleus-localized YAP1 staining in resistant tumors was significantly higher than that in naive tumors in the TMA study containing naive (hormone-responsive) and castration-resistant prostate tumors [32]. In line with the results of their study, we revealed that nYAP1 was overexpressed in chemotherapy-resistant PCa.

With regard to downstream targets of YAP1 signaling, nYAP1 exerts its transcriptional activity mainly by interacting with TEADs [16] and/or Vestigial-like family member 4 (VGLL 4), which competes with YAP-TAZ for TEAD binding [33]. In the docetaxel-resistant $\mathrm{PCa}$ cell line, the expression of nuclear TEAD1 was assessed because several studies have shown that TEAD1 was highly expressed and correlated with poor prognosis in 
patients with $\mathrm{PCa}[34,35]$. However, TEAD1 expression in the nucleus of 22Rv1-DR cells was downregulated in the present study. An in vitro study using Hela cells revealed that the apoptotic role of TEAD1 was modulated by Livin, which is a family member of the inhibitor of apoptosis protein, and YAP1 was not the cofactor involved in this process [24]. The study also discussed that a modest but significant increase in Livin is observed in other types of cancer where TEAD1 is downregulated, such as breast, renal, or bladder cancer. The present study did not elucidate the details of the mechanism underlying high nYAP1 and low TEAD1 expression in docetaxel-resistant PCa cell sublines. Previous studies have described the mechanistic effects of nYAP1 on its regulators, including TEADs [36], VGLL, p160 family protein [37], and ERK-RSK signaling [32], during cancer development. Future studies to evaluate the mechanistic role of nYAP1 in prostate cancer resistance to chemotherapy using our cells and TMAs are imperative to help deepen on our understanding of these processes.

A previous study utilizing normal and cancerous human prostate tissues and PCa cell lines demonstrated that YAP1 and AR formed a protein complex in the nucleus of cancer cells under androgen-dependent and -independent conditions [17]. The study also showed that YAP1-AR interactions are androgen-independent and resistant to a novel anti-androgen, enzalutamide, in CRPC. The study further revealed that YAP1 silencing attenuated cell growth and invasion in vitro and suppressed prostate tumor xenografts in vivo. In the present study, no correlation was found between nAR and nYAP1 based on the expression level of IHC in the TMA slide $(p=0.228, \quad \mathrm{Rs}=-0.092)$. However, in addition to the impact of nYAP1 on BCR, nAR was also significantly associated with $\mathrm{BCR}$ in the univariate analysis. The high nAR expression (activation form) and its splice variant AR-V7 have been shown to be associated with poor BCR-free survival in patients with $\mathrm{PCa}$ who underwent RP with and without neoadjuvant therapy $[38,39]$. Therefore, the interaction between steroid receptors, including its splice variants and Hippo pathway proteins as tissue biomarkers after RP, and its orchestration on chemohormonal resistance in aggressive $\mathrm{PCa}$ should be investigated in future studies.

Previous studies have assessed the molecular characteristics in prostate tissues after CHT in localized PCa treated with RP $[13,14,40,41]$. The expression analyses of selected molecular markers in patients with locally advanced or lymph node metastatic PCa treated with ADT for 1-year and three cycles of docetaxel $\left(35 \mathrm{mg} / \mathrm{m}^{2}\right.$ on days $1,8,15$, and 22 every 6 weeks) showed a high nuclear expression of AR in epithelial cells of both treated and untreated patients [13]. Hence, its stromal expression increased after treatment. In contrast with that study, the expression levels of nAR in the treatment groups decreased significantly, whereas the stromal AR was overexpressed in the treatment groups in the present study. This was partly explained by the fact that the percentage of nAR positivity was immediately decreased after castration (at day 2) and gradually increased up to 120 days [42] in the animal study that evaluated nAR expression in the CWS22 human $\mathrm{PCa}$ xenograft after castration. Therefore, ADT duration along with the protocol of CHT may influence nAR expression after $\mathrm{CHT}$, although the exact reason for the discrepancy between nAR expression in our clinical PCa specimens after CHT and nAR expression in the specimens used in the previous study was not clarified. It would be intriguing to investigate the longitudinal difference of nAR expression in the same patients with biopsy and surgical specimens at different time points after NHT and CHT.

A study that evaluated comprehensive RNA expression analyses of tissues in patients with high-risk localized $\mathrm{PCa}$ who underwent neoadjuvant docetaxel $\left(36 \mathrm{mg} / \mathrm{m}^{2}\right)$ weekly for 6 months showed no genes with large $(>5$ fold) expression changes between treated and untreated prostate tumors [43]. However, a gene set composed of genes involved in androgen and estrogen metabolism was found to be coordinately upregulated in treated samples in the gene set enrichment analysis [43]. Specifically, the RNA expression of metabolic enzymes that decreased the levels of active androgen (e.g., CYP11B1, HSD11B2, HSD17B2, HSD3B1, and UGT2B15) increased, whereas that of enzymes that increased the levels of active androgens decreased (HSD11B1 and CYP11B2) [43]. These lines of evidence suggest the activation of local steroid pathways after neoadjuvant docetaxel administration. In this study, overexpression of GR was found in residual cancer cells and nuclear PR in stromal cells in the CHT group. A previous study demonstrated that acute AR inhibition resulted in GR upregulation in a subset of PCa cells due to relief of ARmediated feedback repression of GR expression [44]. By contrast, decreased expression of the PR in cancerassociated stroma may contribute to elevated SDF-1 and interleukin-6 levels in prostate tumors and enhance prostate tumor progression, whereas the high tumor stromal cell density level $(p=0.045)$ of PR was significantly associated with tumor progression and clinical failure in tumor tissue of patients with T1-3N0 $\mathrm{PCa}$ undergoing RP [27, 45]. In the present study, the low stromal PR expression tended to be associated with poor BCR-free survival (HR 0.45, 95\% CI, 0.20-1.02, $p=$ 0.054). Although no significant impact of the expression of steroid receptors, except nAR, on BCR-free survival was found in the present study, they may potentially be associated with treatment resistance in advanced $\mathrm{PCa}$. 
The study using the tissue specimens collected from the multicenter phase III Cancer and Leukemia Group B 90203, which was designed to assess the impact of ADT plus docetaxel in patients with high-risk localized $\mathrm{PCa}$, demonstrated the molecular analyses of pre-treatment biopsy and postoperative tissues through pathology, DNA sequence, and transcriptome profiling [40]. The study enrolled patients treated with six cycles of docetaxel at a dose of $75 \mathrm{mg} / \mathrm{m}^{2}$ administered every 3 weeks in combination with a luteinizing hormone-releasing hormone agonist for 18-24 weeks, followed by RP. With regard to the somatic mutation, the mean mutant/variant allele frequency (MAF) in post-treated RP specimens was significantly lower than that in either pre-treatment biopsy or untreated RP specimens. In the transcriptome analyses, the majority of the evaluated genes in the neoadjuvant treatment arm were significantly upregulated compared with untreated RP cancers. In terms of AR status, no AR mutation in post-treated RPs (at $>1 \%$ MAF) was detected, and overexpression of AR and AR-V7 was observed in the treated group. Although the study did not assess the expression pattern of AR using IHC, the relationship between nuclear and cytoplasmic expression patterns of AR and its splice variants in IHC and genetic/transcriptomic profiling in each patient may provide new insights into PCa aggressiveness and treatment resistance.

This study has several limitations. First, with regard to the in vitro study, only one cell line was used. Compared with well-established docetaxel-resistant prostate cancer subclones such as PC-3-DR and DU145-DR used in the previous studies [46-48], 22Rv1 has been shown to express full-length $A R$ and its aggressive variant AR-V7 $[49,50]$, which reflects a real-world condition in patients with advanced prostate cancer in recent years. Nevertheless, validation using other cell lines is warranted. Second, tissues without residual mass in human tissue analyses were excluded because we focused mainly on the expression pattern of candidate biomarkers in residual prostate epithelial cells. The present study omitted the impact of stromal expression of the experimental proteins in pT0 tissues. Finally, this study did not compare the expression of each protein in tissues extracted by surgery with that in the pre-treatment biopsies. Longitudinal expression patterns before and after neoadjuvant treatment should be evaluated in a future study. Whether the expression pattern of the pre-treatment biopsies will predict the outcome of CHT still remains unknown.

\section{Conclusions}

In conclusion, the study demonstrated that nYAP is overexpressed in docetaxel-resistant PCa cells and is a candidate prognostic marker for recurrence in patients with high-risk $\mathrm{PCa}$ who underwent $\mathrm{RP}$, followed by CHT. Targeting Hippo pathway signaling and steroid receptors may potentially overcome chemohormonal resistance in PCa.

\section{Supplementary information}

Supplementary information accompanies this paper at https://doi.org/10. 1186/s12885-020-06844-y.

Additional file 1: sTable 1. Patient characteristics in patients with prostate cancer treated with chemohormonal therapy followed by radical prostatectomy.

Additional file 2. Schedule of chemohormonal therapy in patients with high-risk prostate caner in our institution.

Additional file 3. Panel image of TMA including prostates from the high-risk patients with localized PCa who underwent RP with or without neoadjuvant therapies.

Additional file 4: sTable 2. Antibodies used in the immunohistochemical analysis

Additional file 5: sFig.3. Original gel image of western blotting whown in Fig. 1b

Additional file 6: sFig.4. Original gel image of western blotting whown in Fig. 1C

Additional file 7: sFig.5. Original gel image of western blotting whown in Fig. 1d

Additional file 8: sTable3. Details of scored expression levels of steroid receptors and Hippo pathway proteins in TMA. (XLS 278 kb)

\section{Abbreviations}

ADT: Androgen deprivation therapy; AR: Androgen receptor;

BCR: Biochemical recurrence; CRPC: Castration-resistant prostate cancer; FBS: Fetal bovine serum; GR: Glucocorticoid receptor; MAF: Mutant/variant allele frequency; NHT: Neoadjuvant hormonal therapy; PR: Progesterone receptor; RP: Radical prostatectomy

\section{Acknowledgments}

The authors also wish to express their appreciation to Yoko Mitobe, Yuka Izumida, Yukiko Sugiyama, Sayaka Fukuda, Saeko Nakamura, and Masako Nagata for their assistance while conducting the study.

\section{Authors' contributions}

YM: Data collection, statistical analysis, manuscript writing. TN, HM, HS, AK, SK, KN, MS, TI, SS, NT: Technical and material support. YH, HN:

Histopathological analyses. SN, TH: Manuscript editing, supervision. All authors had read and approve of the final manuscript.

\section{Funding}

This study was supported in part by a research grant from the MEXT/JSPS (Kakenhi, No. 16H02679, 16 K10992, 19 K09663) and the Japan Agency for Medical Research and Development (AMED) (grant 18gm0710002h0706). The funding bodies listed here do not have any roles in the design of the study and collection, analysis, and interpretation of data and in writing the manuscript.

\section{Availability of data and materials}

The datasets used and/or analyzed during the current study are available from the corresponding author on reasonable request.

Ethics approval and consent to participate

This study was carried out in compliance with the Declaration of Helsinki. All subjects provided written informed consent for inclusion in the study, which was approved by the institutional review board of Akita University (Ethical Approval No. 1341). 


\section{Consent for publication}

Not applicable.

\section{Competing interests}

No competing financial interests exist.

\section{Author details}

'Department of Urology, Akita University School of Medicine, 1-1-1 Hondo, Akita 010-8543, Japan. ${ }^{2}$ Department of Pathology, Akita University Hospital, Akita, Japan. ${ }^{3}$ Center for Kidney Disease and Transplantation, Akita University Hospital, Akita, Japan. ${ }^{4}$ Department of Urology, Yamagata University School of Medicine, Akita, Japan.

Received: 27 June 2019 Accepted: 7 April 2020

Published online: 15 April 2020

\section{References}

1. Siegel RL, Miller KD, Jemal A. Cancer statistics, 2018. CA Cancer J Clin. 2018; 68(1):7-30.

2. Fitzmaurice C, Akinyemiju TF, Al Lami FH, Alam T, Alizadeh-Navaei R, Allen C, Alsharif U, Alvis-Guzman N, Amini E, Anderson BO, et al. Global, regional, and National Cancer Incidence, mortality, years of life lost, years lived with disability, and disability-adjusted life-years for 29 Cancer groups, 1990 to 2016: a systematic analysis for the global burden of disease study. JAMA Oncol. 2018:4(11):1553-68.

3. Tannock IF, de Wit R, Berry WR, Horti J, Pluzanska A, Chi KN, Oudard S, Theodore C, James ND, Turesson I, et al. Docetaxel plus prednisone or mitoxantrone plus prednisone for advanced prostate cancer. N Engl J Med. 2004;351(15):1502-12.

4. Petrylak DP, Tangen CM, Hussain MH, Lara PN Jr, Jones JA, Taplin ME, Burch PA, Berry D, Moinpour C, Kohli M, et al. Docetaxel and estramustine compared with mitoxantrone and prednisone for advanced refractory prostate cancer. N Engl J Med. 2004;351(15):1513-20.

5. James ND, Sydes MR, Clarke NW, Mason MD, Dearnaley DP, Spears MR, Ritchie AW, Parker CC, Russell JM, Attard G, et al. Addition of docetaxel, zoledronic acid, or both to first-line long-term hormone therapy in prostate cancer (STAMPEDE): survival results from an adaptive, multiarm, multistage, platform randomised controlled trial. Lancet. 2016;387(10024):1163-77.

6. Sweeney CJ, Chen YH, Carducci M, Liu G, Jarrard DF, Eisenberger M, Wong YN, Hahn N, Kohli M, Cooney MM, et al. Chemohormonal therapy in metastatic hormone-sensitive prostate Cancer. N Engl J Med. 2015;373(8): 737-46

7. Narita S, Tsuchiya N, Kumazawa T, Maita S, Numakura K, Obara T, Tsuruta H, Saito M, Inoue T, Horikawa Y, et al. Short-term clinicopathological outcome of neoadjuvant chemohormonal therapy comprising complete androgen blockade, followed by treatment with docetaxel and estramustine phosphate before radical prostatectomy in Japanese patients with high-risk localized prostate cancer. World J Surg Oncol. 2012;10:1.

8. Narita S, Nara T, Kanda S, Numakura K, Saito M, Inoue T, Satoh S, Nanjo H, Tsuchiya N, Mitsuzuka K, et al. Radical prostatectomy with and without Neoadjuvant Chemohormonal pretreatment for high-risk localized prostate Cancer: a comparative propensity score matched analysis. Clin Genitourin Cancer. 2019;17(1):e113-22.

9. Galletti G, Matov A, Beltran H, Fontugne J, Miguel Mosquera J, Cheung C, MacDonald TY, Sung M, O'Toole S, Kench JG, et al. ERG induces taxane resistance in castration-resistant prostate cancer. Nat Commun. 2014;5:5548.

10. Domingo-Domenech J, Vidal SJ, Rodriguez-Bravo V, Castillo-Martin M, Quinn SA, Rodriguez-Barrueco R, Bonal DM, Charytonowicz E, Gladoun N, de la Iglesia-Vicente J, et al. Suppression of acquired docetaxel resistance in prostate cancer through depletion of notch- and hedgehog-dependent tumor-initiating cells. Cancer Cell. 2012;22(3):373-88.

11. Nakazawa M, Paller C, Kyprianou N. Mechanisms of therapeutic resistance in prostate Cancer. Curr Oncol Rep. 2017;19(2):13.

12. Chandrasekar T, Yang JC, Gao AC, Evans CP. Mechanisms of resistance in castration-resistant prostate cancer (CRPC). Transla Androl Urol. 2015;4(3): 365-80

13. Tzelepi V, Efstathiou E, Wen S, Troncoso P, Karlou M, Pettaway CA, Pisters LL, Hoang A, Logothetis CJ, Pagliaro LC. Persistent, biologically meaningful prostate cancer after 1 year of androgen ablation and docetaxel treatment. J Clin Oncol. 2011:29(18):2574-81.
14. Prayer-Galetti T, Sacco E, Pagano F, Gardiman M, Cisternino A, Betto G, Sperandio P. Long-term follow-up of a neoadjuvant chemohormonal taxane-based phase II trial before radical prostatectomy in patients with non-metastatic high-risk prostate cancer. BJU Int. 2007;100(2):274-80.

15. Yu FX, Zhao B, Guan KL. Hippo pathway in organ size control, tissue homeostasis, and Cancer. Cell. 2015;163(4):811-28.

16. Kim MH, Kim J. Role of YAP/TAZ transcriptional regulators in resistance to anti-cancer therapies. Cell Mol Life Sci. 2017;74(8):1457-74.

17. Kuser-Abali G, Alptekin A, Lewis M, Garraway IP, Cinar B. YAP1 and AR interactions contribute to the switch from androgen-dependent to castration-resistant growth in prostate cancer. Nat Commun. 2015;6:8126.

18. Lai CJ, Lin CY, Liao WY, Hour TC, Wang HD, Chuu CP. CD44 Promotes Migration and Invasion of Docetaxel-Resistant Prostate Cancer Cells Likely via Induction of Hippo-Yap Signaling. Cells. 2019;8(4):295.

19. Wang Y, Lieberman R, Pan J, Zhang Q, Du M, Zhang P, Nevalainen M, Kohli M, Shenoy NK, Meng $H$, et al. miR-375 induces docetaxel resistance in prostate cancer by targeting SEC23A and YAP1. Mol Cancer. 2016;15(1):70.

20. Tepper CG, Boucher DL, Ryan PE, Ma AH, Xia L, Lee LF, Pretlow TG, Kung HJ. Characterization of a novel androgen receptor mutation in a relapsed CWR22 prostate cancer xenograft and cell line. Cancer Res. 2002;62(22):6606-14.

21. Hartel A, Didier A, Pfaffl MW, Meyer HH. Characterisation of gene expression patterns in 22RV1 cells for determination of environmental androgenic/ antiandrogenic compounds. J Steroid Biochem Mol Biol. 2003;84(2-3):231-8.

22. Narita S, Tsuchiya N, Saito M, Inoue T, Kumazawa T, Yuasa T, Nakamura A, Habuchi T. Candidate genes involved in enhanced growth of human prostate cancer under high fat feeding identified by microarray analysis. Prostate. 2008:68(3):321-35.

23. O'Neill AJ, Prencipe M, Dowling C, Fan Y, Mulrane L, Gallagher WM, O'Connor D, O'Connor R, Devery A, Corcoran C, et al. Characterisation and manipulation of docetaxel resistant prostate cancer cell lines. Mol Cancer. 2011;10:126.

24. Saupe M, Rauschenberger L, Preuss M, Oswald S, Fussek S, Zimmermann U, Walther R, Knabbe C, Burchardt M, Stope MB. Differential expression of the multidrug resistance 1 (MDR1) protein in prostate cancer cells is independent from anticancer drug treatment and $\mathrm{Y}$ box binding protein 1 (YB-1) activity. World J Urol. 2015;33(10):1481-6.

25. Liu CY, Yu T, Huang Y, Cui L, Hong W. ETS (E26 transformation-specific) upregulation of the transcriptional co-activator TAZ promotes cell migration and metastasis in prostate cancer. J Biol Chem. 2017;292(22):9420-30.

26. Sharifi N. Steroid receptors aplenty in prostate cancer. N Engl J Med. 2014; 370(10):970-1.

27. Grindstad T, Andersen S, Al-Saad S, Donnem T, Kiselev Y, Nordahl MelboJorgensen C, Skjefstad K, Busund LT, Bremnes RM, Richardsen E. High progesterone receptor expression in prostate cancer is associated with clinical failure. PLoS One. 2015;10(2):e0116691.

28. Di Zazzo E, Galasso G, Giovannelli P, Di Donato M, Castoria G. Estrogens and their receptors in prostate Cancer: therapeutic implications. Front Oncol. 2018;8:2.

29. Song $R$, Gu D, Zhang L, Zhang X, Yu B, Liu B, Xie J. Functional significance of hippo/YAP signaling for drug resistance in colorectal cancer. Mol Carcinog. 2018;57(11):1608-15.

30. Liu H, Du S, Lei T, Wang H, He X, Tong R, Wang Y. Multifaceted regulation and functions of YAP/TAZ in tumors (review). Oncol Rep. 2018;40(1):16-28.

31. Jiang N, Hjorth-Jensen $K$, Hekmat O, Iglesias-Gato D, Kruse T, Wang C, Wei W, Ke B, Yan B, Niu Y, et al. In vivo quantitative phosphoproteomic profiling identifies novel regulators of castration-resistant prostate cancer growth. Oncogene. 2015;34(21):2764-76.

32. Zhang L, Yang S, Chen X, Stauffer S, Yu F, Lele SM, Fu K, Datta K, Palermo N, Chen $Y$, et al. The hippo pathway effector YAP regulates motility, invasion, and castration-resistant growth of prostate cancer cells. Mol Cell Biol. 2015; 35(8):1350-62.

33. Jiao S, Wang H, Shi Z, Dong A, Zhang W, Song X, He F, Wang Y, Zhang Z, Wang $W$, et al. A peptide mimicking VGLL4 function acts as a YAP antagonist therapy against gastric cancer. Cancer Cell. 2014;25(2):166-80.

34. Knight JF, Shepherd CJ, Rizzo S, Brewer D, Jhavar S, Dodson AR, Cooper CS, Eeles R, Falconer A, Kovacs G, et al. TEAD1 and c-Cbl are novel prostate basal cell markers that correlate with poor clinical outcome in prostate cancer. Br J Cancer. 2008;99(11):1849-58.

35. Zhou Y, Huang T, Cheng AS, Yu J, Kang W, To KF. The TEAD Family and Its Oncogenic Role in Promoting Tumorigenesis. Int J Mol Sci. 2016;17(1):138. 
36. Zhao B, Ye X, Yu J, Li L, Li W, Li S, Yu J, Lin JD, Wang CY, Chinnaiyan AM, et al. TEAD mediates YAP-dependent gene induction and growth control. Genes Dev. 2008;22(14):1962-71.

37. Holden JK, Cunningham CN. Targeting the Hippo Pathway and Cancer through the TEAD Family of Transcription Factors. Cancers (Basel). 2018; 10(3):81.

38. Chen X, Bernemann C, Tolkach Y, Heller M, Nientiedt C, Falkenstein M, Herpel E, Jenzer M, Grullich C, Jager D, et al. Overexpression of nuclear ARV7 protein in primary prostate cancer is an independent negative prognostic marker in men with high-risk disease receiving adjuvant therapy Urol Oncol. 2018;36(4):161.e119-30

39. Cordon-Cardo C, Kotsianti A, Verbel DA, Teverovskiy M, Capodieci P, Hamann S, Jeffers Y, Clayton M, Elkhettabi F, Khan FM, et al. Improved prediction of prostate cancer recurrence through systems pathology. J Clin Invest. 2007;117(7):1876-83.

40. Beltran H, Wyatt AW, Chedgy EC, Donoghue A, Annala M, Warner EW, Beja $\mathrm{K}$, Sigouros M, Mo F, Fazli L, et al. Impact of therapy on genomics and Transcriptomics in high-risk prostate Cancer treated with Neoadjuvant Docetaxel and androgen deprivation therapy. Clin Cancer Res. 2017;23(22): 6802-11.

41. Bergstrom CP, Ruffell B, Ho CM, Higano CS, Ellis WJ, Garzotto M, Beer TM, Graff JN. Docetaxel and mitoxantrone before radical prostatectomy in men with high-risk prostate cancer: 10-year follow-up and immune correlates. Anti-Cancer Drugs. 2017;28(1):120-6.

42. Kim D, Gregory CW, French FS, Smith GJ, Mohler JL. Androgen receptor expression and cellular proliferation during transition from androgendependent to recurrent growth after castration in the CWR22 prostate cancer xenograft. Am J Pathol. 2002;160(1):219-26.

43. Febbo PG, Richie JP, George DJ, Loda M, Manola J, Shankar S, Barnes AS, Tempany C, Catalona W, Kantoff PW, et al. Neoadjuvant docetaxel before radical prostatectomy in patients with high-risk localized prostate cancer. Clin Cancer Res. 2005;11(14):5233-40.

44. Arora VK, Schenkein E, Murali R, Subudhi SK, Wongvipat J, Balbas MD, Shah N, Cai L, Efstathiou E, Logothetis C, et al. Glucocorticoid receptor confers resistance to antiandrogens by bypassing androgen receptor blockade. Cell. 2013;155(6):1309-22.

45. Yu Y, Lee JS, Xie N, Li E, Hurtado-Coll A, Fazli L, Cox M, Plymate S, Gleave M, Dong X. Prostate stromal cells express the progesterone receptor to control cancer cell mobility. PLoS One. 2014;9(3):e92714.

46. Puhr M, Hoefer J, Schafer G, Erb HH, Oh SJ, Klocker H, Heidegger I, Neuwirt $\mathrm{H}$, Culig Z. Epithelial-to-mesenchymal transition leads to docetaxel resistance in prostate cancer and is mediated by reduced expression of miR-200c and miR-205. Am J Pathol. 2012;181(6):2188-201.

47. Desarnaud F, Geck P, Parkin C, Carpinito G, Makarovskiy AN. Gene expression profiling of the androgen independent prostate cancer cells demonstrates complex mechanisms mediating resistance to docetaxel. Cancer Biol Ther. 2011;11(2):204-12.

48. Codony-Servat J, Marin-Aguilera M, Visa L, Garcia-Albeniz X, Pineda E, Fernandez PL, Filella X, Gascon P, Mellado B. Nuclear factor-kappa B and interleukin-6 related docetaxel resistance in castration-resistant prostate cancer. Prostate. 2013;73(5):512-21.

49. Kim HJ, Park YI, Dong MS. Comparison of prostate cancer cell lines for androgen receptor-mediated reporter gene assays. Toxicol in Vitro. 2006; 20(7):1159-67.

50. Bradley CA. AR-V7 - repress to impress. Nat Rev Urol. 2019;16(5):269.

\section{Publisher's Note}

Springer Nature remains neutral with regard to jurisdictional claims in published maps and institutional affiliations.

Ready to submit your research? Choose BMC and benefit from:

- fast, convenient online submission

- thorough peer review by experienced researchers in your field

- rapid publication on acceptance

- support for research data, including large and complex data types

- gold Open Access which fosters wider collaboration and increased citations

- maximum visibility for your research: over $100 \mathrm{M}$ website views per year

At BMC, research is always in progress.

Learn more biomedcentral.com/submissions 